\title{
Needful-motivational tasks as an effective condition for the technical training of schoolchildren aged 11-12 during the training of the volleyball section
}

Nagovitsyn R.S. ${ }^{1 \mathrm{BCDE}}$, Kudryavtsev M.D. ${ }^{2,4,5,6 \mathrm{ABCDE}}$, Osipov A.Yu. ${ }^{2,3,6 \mathrm{ABCDE}}$, Altuvaini A.H. ${ }^{2,8 \mathrm{ABCDE}}$, Markov K.K. ${ }^{\text {7BCDE}}$,

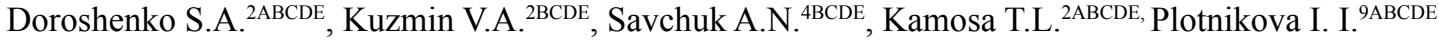

${ }^{1}$ Glazov State Pedagogical Institute named after V.G. Korolenko, Russia

${ }^{2}$ Siberian Federal University, Russia

${ }^{3}$ Krasnoyarsk State Medical University named after professor V.F. Voyno-Yasenetsky, Russia

${ }^{4}$ Krasnoyarsk State Pedagogical University named after V.P. Astafiev, Russia

${ }^{5}$ Reshetnev Siberian State University of Science and Technology, Russia

${ }^{6}$ Siberian Law Institute of the Ministry of Internal Affair of Russia, Russia

${ }^{7}$ National Research Irkutsk State Technical University, Russia

${ }^{8}$ University of Thi-Qar, Irak

${ }^{9}$ Irkutsk State University, Russia

Authors' Contribution: A - Study design; B - Data collection; C - Statistical analysis; D - Manuscript Preparation; E - Funds Collection

\begin{abstract}
Purpose:

To develop a module of need-motivational training tasks of the section "Volleyball for students aged 11-12".

Material: $\quad$ The experiment involved the schoolchildren aged 11-12 $(n=43)$. The schoolchildren had no contraindication to the physical education. Classes according to the author's module of needmotivational teaching tasks were conducted with the secondary school students of the fifth form " $\mathrm{A}$ " ( $n=22$, experimental class). Pupils of the fifth form " $B$ " $(n=21)$ took a traditional training program during the physical education lesson of the "Volleyball" section. The study was conducted for two months (October-December 2018). Each pupil used a fitness bracelet during the class monitoring the heart rate at a physical education lesson. Special testing was used in three blocks. The first block is the calculation of the number of correctly performed technical actions with the ball without a partner. The second block is the calculation of the technical actions in pairs through the net. The third block is an educational game. Statistical analysis of the data was performed using t-student test..

Results: $\quad$ A significant $(p<0.01$ and $p<0.05)$ advantage of the secondary school students of the experimental class was revealed in comparison with another approach to teaching the technical elements of volleyball. A higher mastery level of the basic elements in volleyball was obtained according to the special set of tasks: receiving and passing the ball with two hands from above; receiving and passing the ball with two hands from below (in place, with various types of movements, with lightened and complicated conditions).

Conclusions: It is proved that an increase of the theoretical needful-motivational teaching tasks during the physical education classes has a positive effect on the activation of motor activity of the schoolchildren. The synergetic relationship between theoretical and practical training allows to achieve personal, regulatory, communicative, cognitive and objective results.

Keywords: $\quad$ motivation, need for activity, training, volleyball, physical education, schoolchildren, technical training.
\end{abstract}

\section{Introduction}

The main role of the activity approach in the formation of the younger generation is justified in the field of psychology of physical culture and sports by the experts $[1,2]$. Recently, attention has been focused on the study of the motivational aspects in physical education in various organizations of the middle and higher levels $[3,4]$. Active motivation in the activities of the schoolchildren influences and transforms the surrounding world [5]. Such motivation serves as a means of satisfying a variety of fitness and fitness needs [5]. The motivation is simultaneously a factor in the physical, mental and spiritual formation of a socially useful person $[6,7]$. The

\footnotetext{
(c) Nagovitsyn R.S., Kudryavtsev M.D., Osipov A.Yu., Altuvaini A.H., Markov K.K., Doroshenko S.A., Kuzmin V.A., Savchuk A.N.,

Kamosa T.L., Plotnikova I. I., 2020

doi:10.15561/26649837.2020.0305
}

structure of training activity includes: need, motive, goal, conditions for its achievement $[8,9]$. It represents the unity of two parties - internal (goal, analysis of conditions, action scheme, choice of means) and external (physical activity of the subject, interaction of means with the object or subject of activity, objective processes, result) $[10$, 11]. Any systematic educational activity is necessarily correlated with the concept of need and motive [12, 13]. It is one of the leading components of the educational process. Such a formation of need and motive is important for the harmonious upbringing of a young person and the processes of formation of his physical culture-oriented consciousness [14, 15].

Moreover, the emphasis shifts to the functional chain: "goal-means-result" in a real system of physical education [16]. At the same time, due attention is not paid to the 
need-motivating component [17]. This is most clearly manifested in sports and fitness activities [18, 19]. In this case, the teacher focuses students on the operating side. The teacher determines what and how to do $[18,19]$. In the implementation of this process, cause-effect relationships are ignored: why it is necessary to do just that $[19,20]$. Motivational-semantic guidelines remain without any attention. They are aimed at achieving certain values in the implementation of the technical training [21, 22]. With this approach, the secondary school student masters the system of motor actions at the level of operations [23]. In this case, the goal and means are a set and subsequent reflection does not occur [23]. Ultimately, this does not contribute to the effectiveness of the processes of training and education [24, 25]. In many respects, efficiency is determined by the principle of meaningfulness of the technical actions $[24,25]$. Therefore, it is important disclosing the internal relationships of the needfulmotivational link to the schoolchildren: the study and improvement of the new technical actions during the lesson of physical education [12].

The needful-motivational component is reduced to the following sequence of links: need, motive, interest, value orientations, etc. $[17,26]$. They are the main initial mechanism of educational activity, its motivating and organizing beginning [6]. This approach determines the nature of the chosen goals and the means achieving them. It is accompanied by the student's mental activity [16]. Here his worldview, conviction and conscious attitude to the development of the values of physical culture and sports are formed [27]. In this case, the particular relevance to the formation of the need for motor activity among the schoolchildren is the conscious motivation for the learning process. However, an insufficiently studied issue is the implementation of these processes in the practice of studying the new technical actions during the physical education classes.

Hypothesis of the research. The use of the needfulmotivational training tasks during the lesson of the volleyball section will let to achieve a higher effectiveness level of technical training among the schoolchildren aged 11-12.

The purpose of the research: to develop a module of the need-motivational training tasks of the "Volleyball" section and proving the effectiveness of its implementation of the technical training of the schoolchildren aged 11-12 during the physical education classes.

\section{Material and methods}

Participants: The schoolchildren aged 11-12 years took part in the experiment $(n=43$, fifth form of the secondary school). The schoolchildren had no contraindication to physical education. Classes according to the author's module of need-motivational teaching tasks were conducted with the fifth form " $\mathrm{A}$ " schoolchildren $(n=22$, experimental group $-E G)$. The pupils from the fifth form "B" $(n=21$, control group CG) took a traditional training program of a physical education lesson of the "Volleyball" section. The parents gave informed consent for their children to participate in the study. For the research, classes were selected in which the volleyball section was not previously studied during the physical education lesson. In the previous academic year, these schoolchildren studied outdoor games with the volleyball elements.

Organization of the research: The study was conducted for two months (October-December 2018). Each pupil used a fitness bracelet monitoring the heart rate during a physical education lesson [28]. At the end of each physical education lesson, the teacher collected data of the average heart rate of each pupil of four parts of the lesson: preparatory part (10-15 minutes), training in the first half of the main part (12-14 minutes), improvement in the second half of the main part (10-12 minutes) and the final part (5-7 minutes). At the end of the research (December 2018), control tests of the schoolchildren were conducted testing the technical readiness of the volleyball section. Within two days, the secondary school students passed a set of tests $(\mathrm{n}=7)$. The first testing unit included counting the number of correctly performed technical actions with the ball without a partner: receiving the ball with two hands from above (juggling), receiving the ball with two hands from below (juggling), receiving and passing the ball with two hands from above the wall, receiving and passing the ball with two hands below the wall. The second block of diagnostics was based on the implementation of the technical actions in pairs through the net: receiving and passing the ball with two hands from above through the net, receiving and passing the ball with two hands from below through the net. The third block included a training modified game of volleyball. The difference between this mobile game and the official volleyball game was as follows: the transfer could be carried out an unlimited number of times on its field (but not less than three times); the opponent received the ball by catching the ball with his hands and only then the previously studied technical actions (receiving and passing the ball with two hands from above or below) were implemented.

Currently, the pupils mastering the motor technical actions and pedagogical process of modeling a motor task are considered in three main forms [23]:

- cognitive (reflection of the action as it is);

- prognostic (reflection of the action in terms of its improvement);

- value-orientation which includes value awareness of the need (what needs to be done in a given situation), value-setting (for what), value-semantic decision (understanding the meaning and significance of the chosen means) (Fig. 1):

During the experiment, the physical education lessons $(n=24)$ were implemented weekly three times a week. The exception is vacation for one week. The part of the lessons of physical education $(n=16)$ was devoted to the study of technical actions: receiving and passing the ball with two hands from above; receiving and passing the ball with two hands from below in place, with various types of movements, with lightened and complicated conditions. The part of the lessons of physical education $(n=8)$ was 


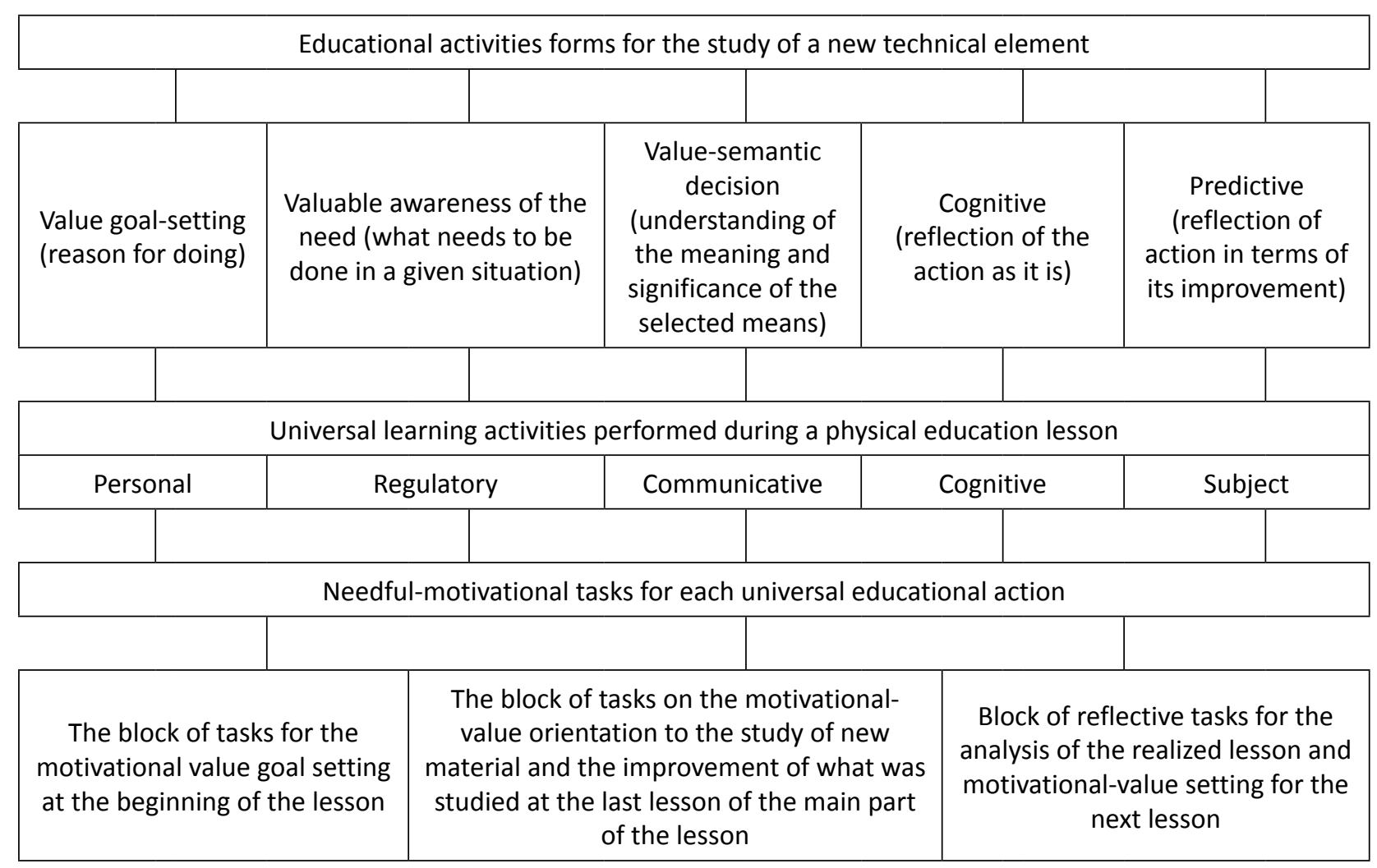

Fig. 1. The author's module of needful-motivational teaching tasks during the physical education classes

devoted to: studying the rules of the game of "Volleyball"; the implementation of general and special physical fitness; the various types of outdoor games, including elements of the Volleyball game. In the experimental and control class, technical training was carried out according to the program for 5-9 forms [29].

An example of the introduction of the author's module during one of the physical education lessons of the section "Volleyball" is presented in table 1.

Statistical analysis: SPSS20 program was used to evaluate the results of studies. The level of reliability of the obtained data was determined using Student's T-test at $\mathrm{p}<0.05$ and $\mathrm{p}<0.01$.

\section{Results}

In the fifth forms two physical education lessons from three per week $(n=16)$ were accompanied by the author's module of needful-motivational training tasks of the volleyball section during the entire experimental work. After each lesson indicated above, the teacher collected data of the heart rate (pulse) of each pupil. In Fig. 2-3 average data are presented for each focus group of heart rate in each of the four analyzed parts of the lesson:

Based on the obtained data of average indicators of heart rate of each student, an unreliable difference ( $p>0.05)$ between the EG and the CG was revealed. It can be reliably stated that the introduction of the needmotivational training tasks at a physical education lesson did not affect the decrease or increase in the average motor load during the volleyball classes. The significance of differences $(p<0.01)$ between the pulse of the schoolchildren from the EG and the CG was revealed in the main part of the lesson. In this part of the lesson, the maximum pulse increase was recorded in the EG compared with the CG. The significance of differences $(\mathrm{p}<0.05)$ between the pulse of the schoolchildren from the EG and the CG of the preparatory and final parts of the lesson was also revealed. In these parts of the physical education lesson, an increase of heart rate was recorded in the CG compared to the EG. A comparative analysis of the heart rate did not reveal significant differences between the EG and the CG at a level p>0.05 in the main part of the lesson.

After the end of the research (December 2018), control tests of the schoolchildren were conducted to test the technical preparedness to the volleyball section in three test blocks. Table 2 presents the average indicators for each of the focus groups for the first and second block. The third block presents the results of 10 games (up to 10 points).

Based on the analysis of the obtained comparative data between the EG and the $\mathrm{CG}$, the significance of the difference was revealed. The exception is the not reliability of the difference $(p>0.05)$ for only one test, "Taking the ball with two hands from the bottom without a partner (juggling)". According to the test "Receiving and passing the ball with two hands from below through the net", the most significant difference $(p<0.01)$ was revealed between the $\mathrm{CG}$ and the EG. The analysis of the effectiveness of the number of won games $(n=9)$ of the third block of diagnostics clearly demonstrates the technical superiority of EG schoolchildren. 
Table 1. The content of the needful-motivational training tasks at a physical education lesson with the topic "Receiving and passing the ball from above with two hands after moving forward"

\begin{tabular}{|c|c|c|c|c|c|}
\hline \multicolumn{6}{|c|}{$\begin{array}{l}\text { The need-motivational tasks for universal educational actions of the "Volleyball" section at a physical education } \\
\text { lesson with the topic: "Receiving and passing the ball from above with two hands after moving forward" }\end{array}$} \\
\hline Personal & Regulatory & & Communicative & Cognitive & Subject \\
\hline \multicolumn{6}{|c|}{ At the beginning of the lesson } \\
\hline $\begin{array}{l}\text { The volleyball player's } \\
\text { gaze fasten eyes on the } \\
\text { ball, which is either } \\
\text { closer or further. This } \\
\text { strengthens the eye } \\
\text { muscles, develops the } \\
\text { eye, and it makes the } \\
\text { organs of vision work } \\
\text { at full "power". } \\
\text { And what do you } \\
\text { think: how does } \\
\text { volleyball influence } \\
\text { the healing of the } \\
\text { body? }\end{array}$ & $\begin{array}{l}\text { In order for us to } \\
\text { succeed a success } \\
\text { during the lesson, } \\
\text { we must achieve } \\
\text { new results } \\
\text { today: learn a } \\
\text { new technical } \\
\text { action; repeat the } \\
\text { material of the } \\
\text { last lesson. At the } \\
\text { previous lesson, } \\
\text { we evaluated } \\
\text { ourselves on a } \\
\text { scale of "Step } \\
\text { forward!». How } \\
\text { do we evaluate } \\
\text { our skills today? }\end{array}$ & \multicolumn{2}{|c|}{$\begin{array}{l}\text { Volleyball teaches } \\
\text { to communication } \\
\text { and effective } \\
\text { communication. } \\
\text { And nowadays - the } \\
\text { more friends, the } \\
\text { more opportunities! } \\
\text { At the game, team } \\
\text { members understand } \\
\text { each other perfectly. } \\
\text { Players on the } \\
\text { volleyball site will } \\
\text { soon turn into the } \\
\text { friends, assistants, } \\
\text { business partners and } \\
\text { advisers outside of } \\
\text { training. And how do } \\
\text { volleyball lessons help } \\
\text { you in communicating } \\
\text { or interacting with } \\
\text { classmates? }\end{array}$} & $\begin{array}{l}\text { At the last lesson, } \\
\text { we studied the new } \\
\text { technical action, } \\
\text { "Receiving and } \\
\text { passing the ball } \\
\text { from above with } \\
\text { two hands". Today } \\
\text { we will improve it } \\
\text { and study a new } \\
\text { topic. And what do } \\
\text { you think: to master } \\
\text { this technical action, } \\
\text { what should be } \\
\text { done today? And } \\
\text { what do you think: } \\
\text { what game action } \\
\text { is most often used } \\
\text { in a game and is } \\
\text { very important for } \\
\text { victory in volleyball? }\end{array}$ & $\begin{array}{l}\text { What unites the } \\
\text { words: Victory, } \\
\text { Russia, Team, Net, } \\
\text { Ball. } \\
\text { We recall the } \\
\text { knowledge gained } \\
\text { at the last lesson: } \\
\text { in which year and } \\
\text { where did volleyball } \\
\text { originate? } \\
\text { "Volleyball was } \\
\text { born in } 1895 \text { in the } \\
\text { USA in college of } \\
\text { Association of Young } \\
\text { Christians. } \\
\text { Physical education } \\
\text { teacher William } \\
\text { Morgan invited } \\
\text { students to throw } \\
\text { the ball through the } \\
\text { tennis net. }\end{array}$ \\
\hline \multicolumn{6}{|c|}{ During the main part of the lesson } \\
\hline $\begin{array}{l}\text { Individualization } \\
\text { of teaching the } \\
\text { technique of } \\
\text { new elements in } \\
\text { volleyball: by gender; } \\
\text { anthropometric } \\
\text { data; by the students } \\
\text { themselves to choose } \\
\text { attacking or defensive } \\
\text { technique. }\end{array}$ & $\begin{array}{l}\text { Students' } \\
\text { independent } \\
\text { choice of tasks } \\
\text { proposed by the } \\
\text { teacher. Dosages } \\
\text { for improving } \\
\text { technical actions. } \\
\text { Forms of self- } \\
\text { monitoring and } \\
\text { control during } \\
\text { training activities. }\end{array}$ & $\begin{array}{l}\text { Prac } \\
\text { to } \\
\text { tech } \\
\text { adn } \\
\text { inte } \\
\text { (tea } \\
\text { usin } \\
\text { and } \\
\text { exp } \\
\text { usin } \\
\text { tech }\end{array}$ & $\begin{array}{lr}\text { ctical activities } \\
\text { improve the } \\
\text { hnique of } \\
\text { nission in an } \\
\text { eractive form } \\
\text { acher and student): } \\
\text { ng comparisons } \\
\text { mini- } \\
\text { hg information } \\
\text { hnology. }\end{array}$ & $\begin{array}{l}\text { Organization } \\
\text { of viewing } \\
\text { video or visual } \\
\text { demonstration } \\
\text { material: studying } \\
\text { new material that } \\
\text { was prepared by } \\
\text { the pupils as their } \\
\text { homework. }\end{array}$ & $\begin{array}{l}\text { Theoretical } \\
\text { explanation of } \\
\text { technical elements } \\
\text { in an interactive } \\
\text { form (teacher and } \\
\text { student) by creating } \\
\text { problem situations. }\end{array}$ \\
\hline \multicolumn{6}{|c|}{ After the final part of the lesson (on the example of the scale "Step forward!" in one line) } \\
\hline $\begin{array}{l}\text { If you think that } \\
\text { the studied topic } \\
\text { today and in general } \\
\text { volleyball lessons } \\
\text { will be useful to } \\
\text { you in your life as a } \\
\text { health or personal } \\
\text { development - take } 2 \\
\text { steps forward. }\end{array}$ & $\begin{array}{l}\text { Take as many } s \\
\text { forward as you se } \\
\text { mark to yourself } \\
\text { the correct execu } \\
\text { of a new techr } \\
\text { action (which we } r \\
\text { studied today). } \\
\text { If you were able } \\
\text { make self-est } \\
\text { in the lesson } \\
\text { determine } \\
\text { conclusions for fur } \\
\text { self-improvement, } \\
\text { then take } 2 \text { more } s \\
\text { forward. }\end{array}$ & & $\begin{array}{l}\text { If you today: } \\
\text { could interact } \\
\text { when working } \\
\text { in pairs and in } \\
\text { a team; You } \\
\text { understood } \\
\text { today teachers } \\
\text { and students } \\
\text { (who showed } \\
\text { technical } \\
\text { actions) - again } \\
\text { take 2 steps } \\
\text { forward. }\end{array}$ & \begin{tabular}{l} 
If you have studied \\
or learned new \\
things during \\
the sports game \\
"Volleyball" today \\
and you were \\
interested - take 2 \\
\multicolumn{2}{c}{ steps forward. }
\end{tabular} & $\begin{array}{l}\text { Who has showed } \\
\text { their homework } \\
\text { today (general } \\
\text { developmental } \\
\text { exercises) } \\
\text { or prepared } \\
\text { presentation } \\
\text { material to study } \\
\text { the new topic of the } \\
\text { lesson - take two } \\
\text { steps forward. }\end{array}$ \\
\hline
\end{tabular}




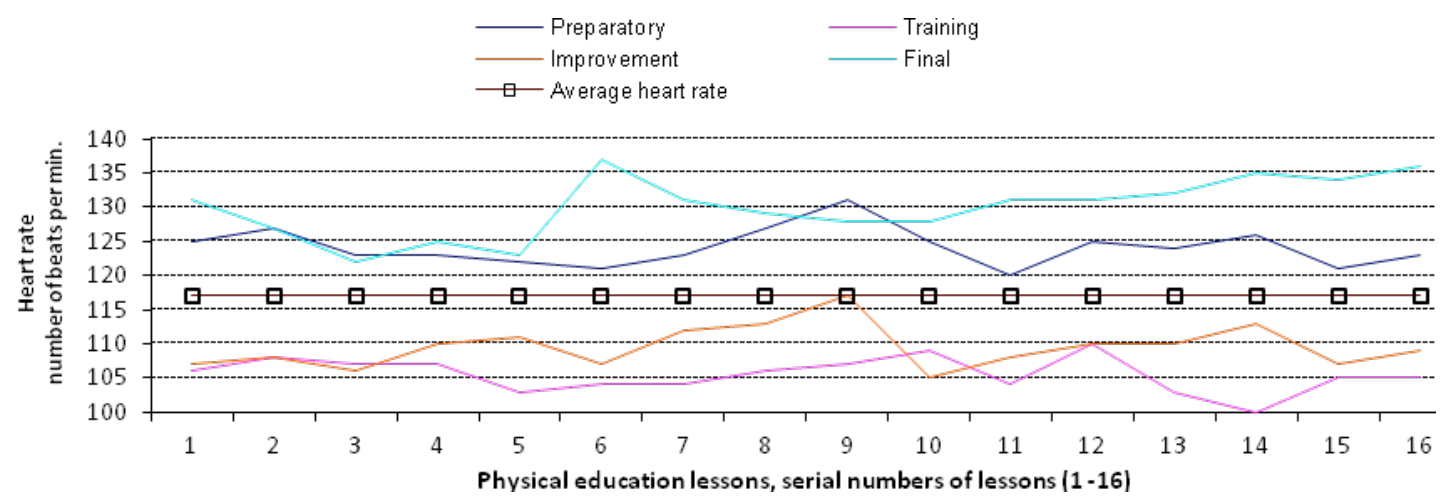

Fig. 2. The results of the pulse of each part of the lesson in the control class
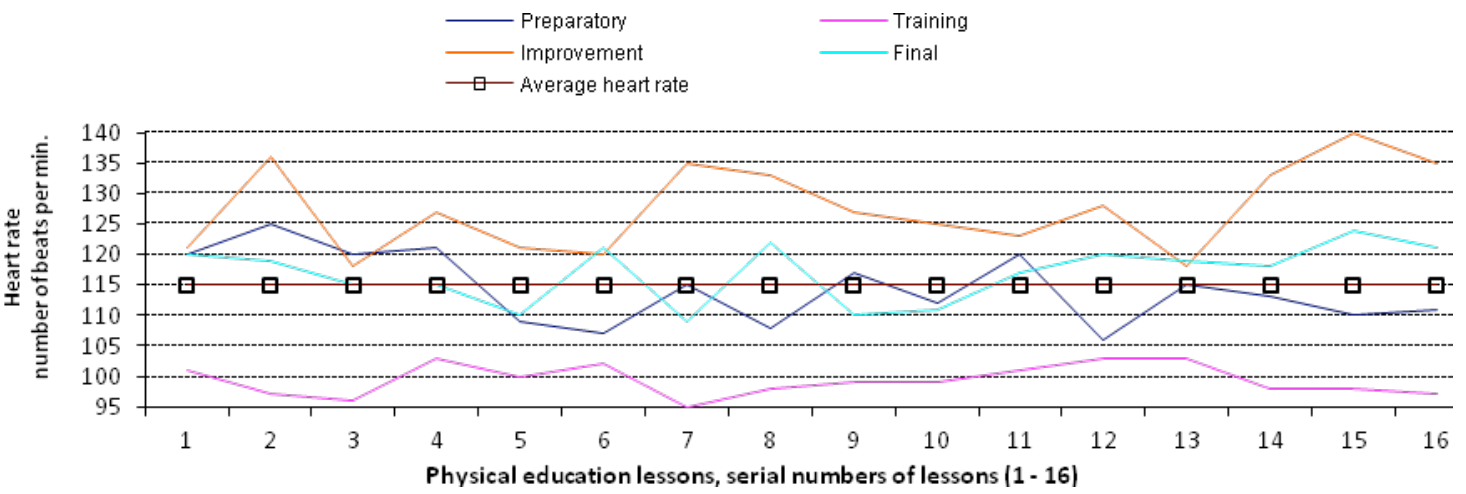

Fig. 3. The results of the pulse of each part of the lesson in the experimental class

Table 2. The results of the research of three test blocks

\begin{tabular}{lllllllll}
\hline Test & \multicolumn{2}{l}{$\begin{array}{l}\text { Reception of the ball } \\
\text { (juggling) }\end{array}$} & \multicolumn{3}{l}{$\begin{array}{l}\text { Reception and transfer of the } \\
\text { ball from the wall }\end{array}$} & \multicolumn{2}{l}{$\begin{array}{l}\text { Receiving and passing the ball } \\
\text { through the net }\end{array}$} & Educational \\
& Above & Below & Above & Below & Above & Below & games $(\mathbf{n}=10)$ \\
\hline EG & 15.3 & 14.8 & 12.8 & 1.2 & 9.1 & 8.1 & 9 \\
CG & 13.6 & 9.5 & 9.2 & 8.4 & 6.6 & 3.3 & 1 \\
P & $>0.05$ & $<0.05$ & $<0.05$ & $<0.05$ & $<0.05$ & $<0.01$ & \\
\hline
\end{tabular}

* During the test after the warm-up, only one attempt was counted before losing the ball

\section{Discussion}

In the implementation of active learning activities, it is recommended that the schoolchildren choose their goals and means of achieving them [25]. The authors prove the priority of independence in the process of learning the schoolchildren a new motor action in the process of physical education and sports [14]. The scientists especially note that it is before the start of the technical action that the formation and implementation of the individuality of the subjects of the training process takes place: the students and teachers [6], athletes and trainer [30]. The process of the joint needful-motivational activity is aimed at mastering a new technical action through an interactive exchange of meanings and values during the volleyball classes. At the same time, cognitive, acmeological, reflective and correctional processes are activated [15, 31]. As the results of this study show, only the systemic formation of all universal educational actions (personal, regulatory, communicative, cognitive and substantive) allows us to achieve reliable $(\mathrm{p}<0.01$ and $\mathrm{p}<0.05)$ positive results. In this case, the time for practical actions is reduced in favor of the implementation of needful-motivational training tasks and reliable technical result is achieved. The experimentally obtained data are confirmed by individual and paired technical readiness. It is confirmed by the pupil's performance of the EG during the implementation of competitive activities.

It is necessary to place special emphasis on the fact that when implementing the educational activities at a physical education lesson, it is necessary using the practical and theoretical training $[16,18]$. This statement is extremely important for understanding the essence of physical education as a sociocultural phenomenon $[3,10]$. Particularly relevant for understanding the implementation of the technical training process for various types and sections of the subject "Physical Culture" is the creation of a theory system of physical culture and sports in a motivational aspect $[10,27]$. A special priority of interpersonal communication during the lesson in the joint physical education activities of the schoolchildren 
is assigned to their inclusion in cultural values, including physical $[7,24]$. In this direction, the spiritual world of the schoolchildren is reflected in motor actions. The pupil receives satisfaction from the final result and from the performance of the technical actions [13, 19]. At the same time, a number of signs of active experiences of a teenager are highlighted. They are associated with the feeling of "fusion of processes of action and consciousness, theory and practice", the state of inspiration from "muscle joy" $[11,21]$. In such cases, the motivational-demanding sphere of thinking dominates. The student enjoys the process of theoretical and practical activity $[18,26]$. The results of our experiment prove the synergistic relationship of theoretical and practical training at a physical education lesson. They supplement the studies of other authors [11, $21,18,26]$. The practical implementation of the module of the needful-motivational training tasks of the volleyball section significantly reduced the motor activity in certain parts of the lesson. The significance of the changes $(p<0.05)$ was recorded during the preparatory and final parts of the lesson, in which the theoretical preparation was used to a greater extent. However, it did not have a significant effect on the average level of heart rate during the lesson $(p>0.05)$. This can be explained by the fact that it was the generated motivation for the result that activated the practical activities of the schoolchildren at the stage of improving the technical actions in the main part of the lesson [28]. As the study shows, in this short period, a significant rise $(p<0.01)$ was recorded in the heart rate increase of the schoolchildren of the experimental class during the lesson compared with the participants of the CG.

\section{Conclusions}

The study proved that the introduction of the module of the needful-motivational training tasks of the volleyball section is effective in the process of training and improving the technical training of the schoolchildren aged 11-12. With the help of regular classes in a special author's set of theoretical and practical tasks, a higher level of mastery of the basic elements was reliably obtained in volleyball: receiving and passing the ball with two hands from above; receiving and passing the ball with two hands from below in place, with various types of movements, with lightened and complicated conditions. The study proved that an increase in theoretical needs-motivational teaching tasks at the beginning and at the end of physical education lesson has a positive effect on the activation of motor activity of the schoolchildren in the main part of the physical education lessons. The synergetic relationship between theoretical and practical training contributes to the formation of personal, regulatory, communicative, cognitive and objective results.

The results of the experiment will be of interest to a wide range of the students and specialists in the field of physical education and sports as well as volleyball players. The author's recommendations on the implementation of diagnostic procedures for monitoring technical preparedness in volleyball will increase the motivation of the pupils setting their individual goals for improving the sports results. Further research will be aimed at studying the influence of the author's module of the need-motivational teaching tasks of different age and qualification categories of the population. An experimental study will cover a larger sample of the subjects with different individual capabilities and needs for the implementation of motor activity.

\section{Conflict of Interest.}

The authors declare that there are no conflicts of interest.

\section{References:}

1. Deci EL, Ryan RM. The "What" and "Why" of goal pursuits: Human needs and the self-determination of behavior. Psychological inquiry. 2000; 11(4): 227-268. https://doi.org/10.1207/S15327965PLI1104_01

2. Gu XL, Zhang T, Chu TL, Keller MJ, Zhang XX. The direct and indirect effects of motor competence on adolescents' mental health through health-related physical fitness. Journal of sports sciences. 2019; 37(17): 1927-1933. https://doi.org/10.1080/02640414.2019.1605652

3. Lubysheva LI. Sports education as basis of formation of personal sports culture. Teoriya $i$ Praktika Fizicheskoy Kultury. 2012; 6: 96-99.

4. Nagovitsyn RS, Bartosh DK, Ratsimor AY, Neverova NV. Modernization of Regional Continuing Pedagogical Education in the "School-College-Institute". European Journal of Contemporary Education. 2019; 8(1):144-156. https://doi.org/10.13187/ejced.2019.1.144

5. Vansteenkiste M, Simons J, Lens W, Sheldon KA, Deci EL. Motivating learning, performance, and persistence: The synergistic effects of intrinsic goal contents and autonomy-supportive contexts. Journal of personality and social psychology. 2004; 87(2): 246-260. https://doi.org/10.1037/0022-3514.87.2.246
6. How YM, Whipp P, Dimmock J, Jackson B. The effects of choice on autonomous motivation, perceived autonomy support, and physical activity levels in high school physical education. Journal of teaching in physical education. 2013; 32(2): 131-148. https://doi.org/10.1123/jtpe.32.2.131

7. Liu JD, Chung PK. Motivational profiles in physical education: evidence from secondary school students in hong kong. Journal of teaching in physical education. 2018; 37(2): 186-196. https://doi.org/10.1123/jtpe.2017-0153

8. Benware CA, Deci EL. Quality of learning with an active versus passive motivational set. American educational research journal. 1984; 21(4): 755-765. https://doi.org/10.2307/1162999

9. Nagovitsyn RS, Bartosh DK, Ratsimor AY, Maksimov YG. Formation of social tolerance among future teachers. European Journal of Contemporary Education. 2018; 7(4): 754-763. https://doi.org/10.13187/ejced.2018.4.754

10.Nikolaev YM. From theory of physical education to theory of physical culture in context of formation of new mind-set. Teoriya i Praktika Fizicheskoy Kultury. 2012; 10: 94-100

11.Ozgul F, Atan T, Kangalgil M. Comparison of the command and inclusion styles of physical education lessons to teach volleyball in middle 
school. Physical educator-US. 2019; 76(1): 182-196. https://doi.org/10.18666/TPE-2019-V76-I1-8481

12.Ntoumanis N. A prospective study of participation in optional school physical education using a selfdetermination theory framework. Journal of educational psychology. 2005; 97(3): 444-453. https://doi.org/10.1037/0022-0663.97.3.444

13.Roure C, Pasco D. The impact of learning task design on students' situational interest in physical education. Journal of teaching in physical education. 2018; 37(10): 24-34. https://doi.org/10.1123/jtpe.2017-0046

14.Gray S, Wright PM, Sievwright R, Robertson S. Learning to Use Teaching for Personal and Social Responsibility Through Action Research. Journal of teaching in physical education. 2019. 38(4): 347-356. https://doi.org/10.1123/jtpe.2018-0190

15.Langdon JL, Webster CA, Monsma EV, Harris BS. A content analysis of teacher autonomy support during a high school volleyball unit. Physical educator-US. 2019; 76(2): 385-409. https://doi.org/10.18666/TPE-2019-V76-I2-8729

16.Sun HC, Chen A. An examination of sixth graders' selfdetermined motivation and learning in physical education. Journalofteachinginphysicaleducation.2010;29(3):262-277. https://doi.org/10.1123/jtpe.29.3.262

17.Deci EL, Ryan RM, Williams GC. Need satisfaction and the self-regulation of learning. Learning and individual differences. 1996; 8(3): 165-183. https://doi.org/10.1016/S1041-6080(96)90013-8

18.Agbuga B, Xiang P, McBride RE, Su XX. Student Perceptions of Instructional Choices in Middle School Physical Education. Journalofteachinginphysicaleducation. 2016;35(2):138-148. https://doi.org/10.1123/jtpe.2015-0010

19.Nikolaev YM. Theoretical Modern physical education theory of the early XXI century. Teoriya i Praktika Fizicheskoy Kultury. 2017; 11: 94-98.

20.Xu HY, Yang J, Shen Z. Research on the cultivation of college students' consciousness of volleyball based on audience theory. Basic \& Clinical pharmacology \& Toxicology. 2019;125(2): 222-223.

21.Ferrer-Caja E, Weiss MR. Predictors of intrinsic motivation among adolescent students in physical education. Research quarterly for exercise and sport. 2000; 71(3): 267-279. https://doi.org/10.1080/02701367.2000.10608907

22.Ryan RM, Deci EL Self-determination theory and the facilitation of intrinsic motivation, social development, and well-being. American psychologist. 2000; 55(1): 68-78. https://doi.org/10.1037/0003-066X.55.1.68

23. Nikolaev YM. Theoretical basics of past, present and future physical education in context of general education and culture development trends. Teoriya i Praktika Fizicheskoy Kultury. 2016; 1: 99-104.

24.Hastie PA, Rudisill ME, Wadsworth DD. Providing students with voice and choice: lessons from intervention research on autonomy-supportive climates in physical education. Sport education and society. 2013; 18(1): 38-56. https://doi.org/10.1080/13573322.2012.701203

25.Haerens L, Aelterman N, Van den Berghe L, De Meyer J, Soenens B, Vansteenkiste M. Observing Physical Education Teachers'Need-SupportiveInteractions in Classroom Settings. Journal of sport \& Exercise psychology. 2013; 35(1): 3-17. https://doi.org/10.1123/jsep.35.1.3

26. Chen SL, Chen A, Sun HC, Zhu XH. Physical activity and fitness knowledge learning in physical education: Seeking a common ground. European physical education review. 2013; 19(2): 256-270. https://doi.org/10.1177/1356336X13486058

27.Balsevich VK. Development of Russian sport science: Problems and ways of solution. Teoriya i Praktika Fizicheskoy Kultury. 2012; 6: 9-12.

28. Galloway R, Booker R, Owens S. Factors leading to discrepancies in accumulated physical activity during school hours in elementary school students. Journal of teaching in physical education. 2019; 38(4): 338-346. https://doi.org/10.1123/jtpe.2018-0232

29.Lyakh V.I. Physical education. 5-9 grades. Work programs. Moscow. Education. 2011.

30.Mosqueda S, Lopez-Walle JM, Gutierrez-Garcia P, GarciaVerazaluce J, Tristan J. Autonomous motivation as a mediator between an empowering climate and enjoyment in male volleyball players. SPORTS. 2019; 7(6): 153. https://doi.org/10.3390/sports7060153

31.Riveras S, Zeng ZH, Gigliello CH, Skelly J. Examining of Youth Volleyball Players' Motivations and Health-Related Behaviors. Research quarterly for exercise and sport. 2019; 90(1): A29-A30. 


\section{Information about the authors:}

Nagovitsyn R.S.; http://orcid.org/0000-0003-4471-0875; gto18@mail.ru; Glazov State Pedagogical Institute named after V.G. Korolenko; Glazov, Russia.

Kudryavtsev M. D.; (Corresponding author); http://orcid.org/0000-0002-2432-1699; kumid@yandex.ru; Siberian Federal University; Reshetnev Siberian State University of Science and Technology; Krasnoyarsk State Pedagogical University of V.P. Astafyev; The Siberian Law Institute of the Ministry of Internal Affair of Russia; Krasnoyarsk, Russia.

Osipov A.Yu.; http://orcid.org/0000-0002-2277-4467; ale44132272@yandex.ru; Siberian Federal University; Krasnoyarsk State Medical University named after professor V.F. Voyno-Yasenetsky; Siberian Law Institute of the Ministry of Internal Affair of Russia; Krasnoyarsk, Russia.

Altuvaini A. H.; https://orcid.org/0000-0002-8778-8827; aah88440@gmail.com; Siberian Federal University; Krasnoyarsk, Russia; University of Thi-Qar; Nasiriya, Irak.

Markov K.K.; http://orcid.org/0000-0003-1893-5907; k_markov@mail.ru; National Research Irkutsk State Technical University; Irkutsk, Russia.

Doroshenko S. A.; http://orcid.org/0000-0002-8593-1685; trisha246@yandex.ru; Siberian Federal University; Krasnoyarsk, Russia.

Kuzmin V.A.; http://orcid.org/0000-0002-4190-1628; atosn35@ mail.ru; Siberian Federal University; Krasnoyarsk, Russia.

Savchuk A. N.; https://orcid.org/0000-0003-0639-6950; Savchuk.A.n@mail.ru; Krasnoyarsk State Pedagogical University named after V.P. Astafyev; Krasnoyarsk, Russia.

Kamosa T. L.; https://orcid.org/0000-0001-9572-5140; tat.kamoza@yandex.ru; Siberian Federal University; Krasnoyarsk, Russia.

Plotnikova I. I.; http://orcid.org/0000-0003-2851-2369; ira.plotnikova1978@mail.ru; Irkutsk State University; Irkutsk, Russia.

Cite this article as:

Nagovitsyn RS, Kudryavtsev MD, Osipov AYu, Altuvaini AH, Markov KK, Doroshenko SA, Kuzmin VA, Savchuk AN Kamosa

TL, Plotnikova II. Needful-motivational tasks as an effective condition for the technical training of schoolchildren aged

11-12 during the training of the volleyball section. Pedagogy of physical culture and sports, 2020;24(3):129-136.

https://doi.org/10.15561/26649837.2020.0305

This is an Open Access article distributed under the terms of the Creative Commons Attribution License, which permits unrestricted use, distribution, and reproduction in any medium, provided the original work is properly cited (http://creativecommons.org/licenses/by/4.0/deed.en).

Received: 20.11.2019

Accepted: 24.12.2019; Published: 05.01.2020 